Studies in African Linguistics

Volume 26, Number 2, Fall 1997

\title{
TOWARD A TYPOLOGY OF DIRECTIONAL MOTION FOR AFRICAN LANGUAGES*
}

\author{
Ronald P. Schaefer and Richard Gaines \\ Southern Illinois University at Edwardsville
}

\begin{abstract}
This paper examines the syntactic and semantic expression of basic directional motion and its manner counterparts across the four language phyla of Africa. We sample languages from each phylum, concentrating on basic, non-deictic, directional motion and its counterpart in which motion, direction, and manner of motion occur simultaneously. Two primary findings emerge. Across Africa, basic directional motion tends to be verb-framed with respect to direction; it conflates the semantic components Motion+Direction in verbs equivalent to 'enter, circle, traverse'. Manner of motion, while maintaining this lexicalization pattern, syntactically registers a Motion+Direction verb and its linear order relative to a Manner verb through either of two primary strategies. Manner precedes Motion+ Direction when the two verbs are conveyed through serial verb sequences, verb compounding, or verb coordination. Manner follows Motion+Direction when the former is specified as a deranked verbal form, e.g., as a gerundive, or as part of a deranked clause, e.g., a subordinate clause.
\end{abstract}

\section{Introduction}

The linguistic structuring of physical motion events continues to be of keen interest to investigators exploring the interface between syntax and the lexicon [Gruber 1976, Jackendoff 1990, Talmy 1985, 1991, Levin and Rappaport-Hovav 1995]. To encode these events, two semantic elements are fundamental: MOTION, the process

* Earlier versions of this paper were presented at the 27th Annual Conference on African Linguistics, University of Florida, Gainesville, and at the 26th Colloquium on African Languages and Linguistics, Leiden, The Netherlands. We would like to thank the respective audiences for their helpful criticism of earlier versions of this paper. Preparation of this paper was supported by the National Science Foundation through a grant to the first author, SBR \#9409552, and a Research Experience for Undergraduates Supplemental grant to the second author. 
of change in the spatial position of one entity relative to another, and DIRECTION, the course or trajectory taken by the moving entity. In a language like German, each of these elements is typically packaged in a distinct lexical form, e.g., Motion in a verb such as gehen and Direction in a preposition like über: Der Junge ging über die Strasse 'The boy went across the road.' In French, however, these same elements are incorporated in a single lexical form, as shown by traverser 'to cross', in Le garçon traversait la rue 'The boy was crossing the road.'

Directional motion events stand in contrast to events lacking Direction but not Motion. These non-directional- or confined-motion events signal the orientation of a reference point to a moving entity. In French, this is accomplished through adpositions like dans in (1a) or devant in (1b).
(1)
a. il court dans la chambre he run LOC the room 'he runs inside the room'
b. il court devant la maison he run in-front-of the house 'he runs in front of the house'

That orienting adpositions in these examples do not realize Direction is suggested by their occurrence with contrasting directions. The form dans is found with the distinct directions 'up' and 'down' in (2). Although not bearers of direction, French adpositions occur in directional motion structures as characterizations of reference point objects. In (2), dans fosters construal of the reference point objects, chambre and cave, as enclosures for the direction bearing verbs monter 'to ascend, to move up to' and descendre 'to descend, to move down to.'

(2) a. il monte dans sa chambre he ascend LOC his room 'he ascends to his room' 'he moves up to his room'

b. il descend dans la cave he descend LOC the basement 'he descends to the basement' 'he moves down to the basement'

Further evidence that adpositions can express orientation rather than direction is highlighted by directional constructions in French. When pronominal forms designate reference point objects, the directional interpretation of the verbs monter and descendre is retained, even though the orienting adposition is not. 
(3) a. il y monte

he there ascend

'he ascends there'

b. il y desend

he there descends

'he descends there'

Orienting adpositions may serve to identify a directional events bounded or unbounded character [Jackendoff 1983]. Through their presence, they signal that the reference point binds the moving entity to an initial or final locus, a source or goal, respectively. In (3a), de 'from' marks initial locus or source, whereas its absence with an unbounded motion event in $(3 \mathrm{~b})$ reveals a reference point serving as neither source nor goal.

(4) a. il sort de la chambre

he exit from the room

'he exits from the room'

b. il longe la rivière

he move-along the river

'he moves along the river'

Returning to basic directional motion, we find a contrast in its lexical packaging which Talmy [1985, 1991] differentiates under the rubric verb-framing vs. satellite-framing. His crosslinguistic analysis of directional motion reveals how languages tend toward either verb-framing, e.g., the French verb traverser in (5a) incorporating Motion+Direction, or satellite-framing, e.g., the German verb gehen (ging) in (5b) expressing Motion in conjunction with a grammatical satellite in the form of a preposition or particle über conveying Direction.
a. Le garçon traversait
la rue

[Motion+Direction]

'the boy was crossing the road'

b. Der Junge ging über die Strasse

[Motion] [Direction]

'the boy went across the road'

In languages like English both verb-framing and satellite-framing occur as a result of historical borrowing [Talmy 1985]. Satellite-framing constructions (move into: The woman moved into the house) reflect an older Anglo-Saxon pattern, 
whereas verb-framing constructions (enter: The woman entered the house) show the influence of borrowing from Norman French.

Events involving the simultaneous occurrence of Motion, Direction, and Manner reveal still additional lexicalization paths. Comparing English run with French courir 'to run', we see that Manner in English tends to conflate with Motion in the main clause verb, run, leaving Direction to be expressed in the adposition into (6). Manner in French, however, tends not to conflate with Motion, occurring instead in a gerundive form, courant, relative to a main clause verb incorporating Motion and Direction, e.g., entrer (7).
(6) The woman ran
into
the house
[Motion+Manner] [Direction]
(7) il entre
[Motion+Direction]
dans la maison en courant
Manner
'he enters the house by running'
'he runs into the house'

This French example points to one of several possible syntactic strategies for expressing manner of directional motion. Motion+Direction enter can link to Manner run when both are coordinate in a ranked or main clause (The woman ran and entered the house), Manner is deranked in a gerundive or adposition (The woman entered the house while running), or Manner is deranked in a subordinate clause (The woman entered the house, while she was running).

As a final point regarding manner of directional motion, we will distinguish between transextensional and transpositional events. The latter involve the ballistic displacement of a transitive direct object but not its accompanying subject, e.g., The child threw the ball onto the table, or of an intransitive subject, e.g.,The child jumped onto the table (in a single bound). 1 Transextensional events, on the other hand, refer to extended, non-ballistic displacement of a transitive direct object and its accompanying subject vis-à-vis a locative reference point, e.g., The child dragged the blanket into the room or of an intransitive subject, e.g., The child ran into the room. This distinction, if not the terminology, appears consistent with discussions in Shibatani [1976] and Talmy [1976, 1985].

In this paper we undertake an initial examination of the linguistic structuring of basic directional motion and manner of directional motion across the four language

\footnotetext{
1 That the distinction between transextensional and transpositional displacement applies to intransitive as well as transitive verbs is suggested by contrasting structures in the Edoid language Emai. Transextensional events with the intransitive manner verb la 'to run' require a directional verb, $o$ 'to enter,' in series, $\varrho$ lá ó vbí úkpóde [he run enter LOC road] 'he ran onto the road,' whereas transpositional events with the intransitive manner verb vboo 'to jump,' require the augmentative verb $f i$ 'to throw' and the direction conveying change of location particle $\underline{Q} \underline{\Omega} v b \underline{b} \underline{\alpha}$ fi $\underline{\Omega}$ vbi otoi 'he jumped onto the ground.'
} 
phyla of Africa. We examine dictionary and grammar entries for languages in each phylum, concentrating on verbs expressing basic, non-deictic, directional motion. ${ }^{2}$ We then investigate individual languages with respect to basic motion and manner of motion events, discussing each in separate sections. For these comparisons, we rely on a set of directional types as representative, including events which might be differentially construed as to their boundedness, e.g., 'to enter, move into' as bounded and 'to move around, to circle' as unbounded. Although the tentative nature of our findings must be emphasized, their import may prove useful to future, more detailed investigations of individual languages and language families. We turn now to analysis of languages in the phyla Afro-Asiatic, Khoisan, NiloSaharan, and Niger-Kordofanian. ${ }^{3}$

\section{Basic Directional Motion}

Basic motion events simultaneously display Motion and Direction. Lexical expression of these two components in African languages reveals a very strong tendency. Across Africa, basic motion events tend to be verb-framed with respect to Direction. That is, the components Motion+Direction merge in verbs equivalent to 'enter, exit, traverse'.

2.1. Afro-Asiatic. Various languages in the Afro-Asiatic phylum evince verbs which conflate Motion+Direction. Arabic [Wehr 1979] shows dakhal 'to enter', tarak 'to leave', and sa?ad 'to ascend'; Amharic [Leslau 1973] gebba 'to enter',

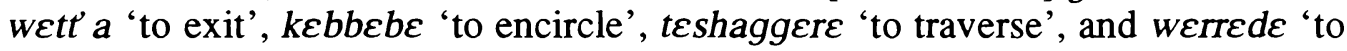
descend'; and Mupun [Frajzyngier 1987] $k a$ 'to ascend' and siam 'to descend'.

Scrutiny of how semantic components are lexically apportioned in basic motion clauses in the Afro-Asiatic language Hausa [Newman and Ma Newman 1977] also discloses the incorporation of Motion+Direction. Hausa displays a consistent pattern of packaging Motion and Direction in the main verb of simple clauses. The verb forms keewaya 'circle', shiga 'enter', hau 'ascend', and fita 'exit' in (8) incorporate the semantic concept of Motion and a distinct Direction type. In addition, we see in (8d) that the adposition daga 'from' identifies its accompanying nominal as initial locus or source of a motion event whose direction is verb-framed, e.g., fita 'to exit, to move out'.

2 We recognize that dictionary or grammar entries in themselves may not be the most dependable source of information concerning the syntactic allocation of semantic components, particularly in the domain of motion. Yet, dictionary entries have been insightfully used to uncover lexical patterning [Dixon 1982].

3 For generously giving of their time and energy we would like to thank the following language consultants: Lionel Bender for Amharic, Robert Carlson for Supyire, Francis Egbokhare for Emai, John Hutchison for Kanuri, Kumbirai Mkanganwi for Shona, Joe McIntyre, Paul Newman, and Russell Schuh for Hausa, and Jan Snyman for !Xûu. Tswana data derive from Cole [1955] and fieldwork completed by the first author. For all languages in this paper, tonal values are presented only where information was marked and so provided by consultants. 
(8) a. yaaròo yaa keewàyaa wutaa boy he circled fire 'the child circled the fire'

b. yaaròo yaa shìga daakìi boy he entered room.the 'the boy entered the room'

c. bàreewâ-r taa hau tsaunì gazelle-the she ascended hill 'the gazelle ascended the hill'

d. dookìi yaa fita dàgà shingee horse-the he exit from corral 'the horse exited the corral'

2.2. Khoisan. Basic directional motion in languages of the Khoisan phylum is verb-framed. In Ju'Hoan [Dickens 1994], we find !' an 'to ascend', kharu 'to descend', g!a?ama 'to enter', glai 'to exit', n//humi 'to encircle', and thaha 'to move through'; in !Xoo [Traill 1994] !ai 'to encircle', ! ua 'to exit', ulu 'to enter', tholo 'to descend', and !ahle 'to ascend;' and in Nama [Hagman 1977] f'oa 'to go out, exit' and peé 'to go away'.

Examination of lexical structure in clauses of the Khoisan language !Xûu [Snyman 1970] shows the fusion of Motion+Direction. ${ }^{4}$ In (9), each of the verbs g! a?amaa 'enter', /l'hamm 'circle', g/ai 'exit', and $\neq x u r u$ 'ascend' lexicalizes the fact of Motion and the Direction of a moving object.

(9) a. !'hoama kaa g!a?ama tš'ul'ho boy the enter kraal

'the boy entered the kraal'

b. da? ama kaa /'hamm da?a child the circle fire 'the child circled the fire'

c. loe kaa g/ai ť̌' 'u/'ho horse the exit kraal 'the horse exited/went out of the kraal'

4 Symbols used to express click sounds include the following: / for dental; // for alveolar lateral; ! for alveolar; and $\neq$ for palatoalveolar. In conjunction with clicks, " $g$ " indicates voicing, "' $h$ " delayed aspiration, and " $n$ " nasal flow. 


\section{d. !'haa kaa $\neq$ xuru n! um antelope the ascend hill 'the antelope ascended the hill'}

2.3. Nilo-Saharan. Nilo-Saharan languages, as suggested by our sample, express basic directional motion events with a Motion+Direction verb. We find in Luo [Creider 1993] lworo 'to encircle', donjo 'to enter', ciko 'to move towards', kadho 'to pass, go beyond'; in Fur [Jakobi 1990] -kar- 'to enter', -jaab- 'to cross', -ufuno'to descend', -kur- 'to go out;' in Nandi [Creider and Creider 1993] $k \varepsilon$ :-la:ny 'to ascend', $k \varepsilon$ :-re:k 'to descend', $k \varepsilon$ :-la:nta 'to cross', $k i$ :-mu:t 'to encircle', and $k$ oma:nta 'to move out;' and in Turkana [Dimmendaal 1983] lom 'to enter' and Irrk 'to encircle'. 5

A more detailed inquiry of Kanuri, a Nilo-Saharan language of Nigeria [Hutchison 1981, Cyffer 1994], bolsters the verb-framing contention. Kanuri consistently merges Motion+Direction in a main clause verb. In (10), kargawo 'enter', jəwa 'ascend', dəriz 'circle', and coluwo 'exit, leave' each compresses Motion as well as Direction into a single verb form. We also see in these examples that the suffixes -ro and -lan serve an orientation function particular to goal (Go) and source (So), respectively. 6 That -ro expresses orientation rather than direction is suggested by its compatibility with the distinct directions of kargawo 'enter' in (10a) and of jowa 'to ascend' in (10b).

(10) a. tada-do nyim-ro kargawo child-the room-Go 3S.entered 'the child entered the room'

b. ngəri-də kawu-ro jəwa gazelle-the rock-Go 3S.ascended 'the gazelle ascended the mountain'

c. tada-də kannu-do-ga dəriz-ə kəlwono child-the fire-the-ACC 3S.circle-and 3S.join 'the child circled the fire all the way'

5 The symbols “a, $\varepsilon$, I, o" represent vowels with [ -ATR ], while "a, e, i, o" represent vowels with [+ATR ].

6 The following abbreviations are used in glosses throughout the paper:

$\begin{array}{llllll}\text { ACC } & \text { accusative } & \text { Go } & \text { goal } & \text { PRF } & \text { perfective } \\ \text { APP } & \text { applicative } & \text { IMP } & \text { imperfective } & \text { PST } & \text { past } \\ \text { CONS } & \text { consecutive } & \text { LOC } & \text { locative } & \text { S } & \text { singular } \\ \text { CONT } & \text { continuous } & \text { NOM } & \text { nominative } & \text { SC } & \text { subject concord } \\ \text { DIS } & \text { displacement } & \text { PRT } & \text { participial } & \text { So } & \text { source } \\ \text { GEN } & \text { genitive } & & & & \end{array}$

A number alone refers to a noun class in Tswana and Shona glosses. 
d. for-do suro fato-be-lan culuwo horse-the inside house-GEN-So 3S.left

'the horse left the house'

'the horse went out from inside the house'

2.4. Niger Kordofanian. As with other phyla in Africa, Niger-Kordofanian displays a propensity to compress Motion+Direction in verbs expressing basic motion events. In Yoruba [Abraham 1962], we find wo 'to enter', koja 'to traverse, pass by', goke 'to ascend', and dabu 'to cross'; in Igbo [Uwalaka 1988, Welmers and Welmers 1968] bhara 'to enter', furu 'to exit', and shi 'to move through'; in Kana [Ikoro 1996] yii 'to enter' and siraa-ke 'to descend'; and in Fula [De Wolf 1995] naata 'to enter', fe?a 'to cross', lasde 'to circle', and huula 'to traverse'.

Analysis of lexicalization patterns in clauses of individual languages highlights more forcefully Niger-Kordofanian's verb-framing character. Supyire, a Gur language of West Africa [Carlson 1994], conveys basic directional motion through verb-framing. In the simple clauses of (11), the verbs jye 'enter', fworo 'exit', dugo 'ascend', and jyiile 'cross' conflate Motion+Direction. Moreover, the orientation function of accompanying adpositions is evident in (11a) and (11b), where $e$ 'inside' occurs with the contrasting directions of jye 'enter' and fworo 'exit'.

(11) a. u a jye ba-ge e

3S PRF enter house-the inside

's/he entered the house'

b. $u$ a fworo ba-ge e

3S PRF exit house-the inside

's/he exited the house'

c. u a dugo nyang-ke na

3S PRF ascend hill-the LOC

's/he climbed up the hill'

d. u a ba-nyi jyiile

3S PRF river-the cross

' $\mathrm{s}$ /he crossed the river'

Basic directional motion events in Emai, an Edoid language of West Africa [Schaefer 1987], reflect verb-framing. In (12) the main clause verb consistently packages the components Motion+Direction. Included among Emai's Motion+ 
Direction verbs are $o$ 'enter', shoo re 'exit', lagaa 'circle', and heen 'ascend.'7 Since two of these verbs with contrasting directions, $o$ 'enter' and shoo re 'exit', require the locative adposition $v b i$, the latter's orientation rather than directional function becomes evident.

12. a. ólí ómohe ó vbi iwe the man enter LOC house 'the man entered the house'

b. Qólí ómohe shóó vbi iwe ré the man exit LOC house DIS 'the man exited the house'

c. óli ógmo $\underline{Q} \quad \underline{Q} \quad$ lágaa óli iwe the child SC CONT circle the house 'the child is circling the house'

d. óli ógohe héén oólí ókoó the man ascend the hill 'the man ascended the hill'

Tswana, a Bantu language of southern Africa [Cole 1955, Schaefer 1985], is also verb-framing with respect to basic directional events. As indicated by the stems -tsen- 'enter', -tsw- 'exit', and -potolog- 'circle' in (13), the two components Motion and Direction fuse in Tswana verbs.

(13) a. mò-símàné ó-tsén-à mó-tlù-ng

1-boy he-enter-IMP inside-house-LOC

'the boy is entering the house'

b. mò-símàné ó-tsw-à mó-tlù-ng

1-boy he-exit-IMP inside-house-LOC

'the boy is leaving the house'

c. mò-símàné ó-pótólòg-à pètsè

1-boy he-circle-IMP well

'the boy is circling the well'

7 Orthographic conventions for Emai follow Schaefer [1987], where "e" represents a half-open front vowel, "o" a half-open back vowel, "vb" a voiced bilabial approximant. High tone is marked with an acute accent; low tone is unmarked. 
A final Bantu language, Shona [Fortune 1955], also utilizes verb-framing. To encode basic motion events, it melts Motion and Direction into a single verb, as indicated by the stems -pind- 'enter', -poterer- 'circle', and -darik- 'cross'.

(14) a. mu-ana u-aka-pinda mumba

1 -child 1-PST-enter room

'the child entered the room'

b. mu-ana u-aka-poterera tafura

1-child 1-PST-circle table

'the child circled the table'

c. mu-rume u-aka-darika musha

1-man 1-PST-cross kraal

'the man crossed the kraal'

\section{Manner of Directional Motion}

Our preliminary analysis of how African languages encode manner of directional motion uncovers three major tendencies. First, African languages hold to a verbframing strategy for Direction; they continue to lexicalize Motion+Direction. Second, they convey the component Manner through a verb form separate from Motion+Direction. And third, African languages in our sample register the linear order of their Motion+Direction and Manner verbs through either of two strategies. Manner precedes Motion+Direction when the two verbs are expressed by serial verb sequences, verb compounding, or verb coordination:

[Manner] [Motion+Direction].

Manner follows Motion+Direction when the former occurs as a deranked verbal form, i.e., as a gerundive, or in a deranked clause, i.e., in a subordinate or dependent clause:

\section{[Motion+Direction] [Manner].}

We turn now to the lexical partitioning of these semantic components in each of Africa's four language phyla.

3.1. Afro-Asiatic. We continue to examine Hausa as representative of AfroAsiatic. While Hausa retains Motion+Direction packaging for manner of motion events, it syntactically expresses Manner in either of two structures. Manner verbs surface in a nominalized form as object of an adposition or as a predicative linked to $B E$ in subordinate circumstantial clauses. 
Hausa's intransitive Manner verbs reflect both strategies. In one, an adposition phrase accepts a nominalized form of the Manner verb, while the main clause verb continues to incorporate Motion+Direction. The nominalized verb forms guje 'a run', guduu 'running', rarrafee 'a-crawl', sukwane 'a-gallop', and sukuwaa 'galloping' in (15) serve as objects of the prepositions a 'at' or da 'with.' Each conveys Manner from its deranked position, whereas the verbs shiga 'enter', zagay 'circle', fita 'exit', and hau 'ascend' continue to specify Motion+Direction.

(15) a. yaaròo yaa shìga daakìi à gùje

boy he entered room at a-run

'the boy entered the room at a run'

'the boy ran into the room'

b. yaaròo yaa shìga daakìi dà gudùu boy he entered room with running 'the boy entered the room running' 'the boy ran into the room'

c. yaaròo yaa zaagàyà wutaa à ràrràfe boy he circle fire at a-crawl 'the child circled the fire at a crawl' 'the child crawled around the fire'

d. yaaròo yaa zaagàyà wutaa dà ràrràfee boy he circle fire with crawling 'the child circled the fire crawling' 'the child crawled around the fire'

e. dookìi yaa fita dàgà shingee à sùkwàane horse-the he exited from corral at a-gallop 'the horse left the corral at a gallop' 'the horse galloped out of the corral'

f. dookìi yaa fita dàgà shingee dà sukùwaa horse-the he exited from corral with galloping 'the horse left the corral galloping' 'the horse galloped out of the corral'

g. bàreewâ-r taa hau tsaunìi à gùje gazelle-the she ascended hill at a-run 'the gazelle ascended the hill at a run' 'the gazelle ran up the hill' 
h. bàreewâ-r taa hau tsaunìi dà gudùu gazelle-the she ascended hill with running 'the gazelle ascended the hill running' 'the gazelle ran up the hill'

As part of a second strategy, intransitive Manner verbs are expressed through clause-level deranking. While the main clause verb keewaya 'circle' in (16) conflates Motion+Direction, the nominalized Manner verb rarrafee 'crawling' occurs in a circumstantial BE clause.

(16) yaaròo yaa keewàyaa wutaa yanàa ràrràfee boy he circled fire he-was crawling 'the boy circled the fire while he was crawling'

'the boy crawled around the fire'

Structures realized by either of these strategies never locate Manner in the main clause verb. In (17a) and (17b), rarrafee 'crawl' appears as a main clause verb, and keewaye and zagay, incorporating Motion+Direction, occur as deranked verbs in a circumstantial clause and an adposition phrase, respectively. Neither is grammatical. Intransitive Manner verbs never precede Motion+Direction verbs in Hausa under conditions of clausal or phrasal deranking.

(17) a. *yaaròo yaa yi ràrràfee yanàa keewàyè wutaa boy he did crawl he-was circling fire 'the boy crawled while he was circling the fire' 'the boy crawled around the fire'

b. *yaaròo yaa rarràfee dà zaagàyà wutaa boy he crawl with circling fire 'the boy crawled circling the fire' 'the boy crawled around the fire'

Transitive verbs in Hausa utilize only a single strategy for manner of directional motion. While the main clause verb incorporates Motion+Direction, zaagaya 'circle' and hau 'climb' in (18a) and (18b), a circumstantial clause containing the verb jan 'pull' specifies Manner. Constructions of this type never exhibit the converse order with respect to their predicates. The Manner verb jaa 'pull' does not appear in the main clause, and the Motion+Direction verbs zaagaa 'circle' and hawan 'climb' fail to occur in a deranked circumstantial clause. Again, Manner never precedes Motion+Direction under Hausa's clausal deranking condition (19). 
(18) a. mùtumìn yaa zaagàyà wutaa yanàa jân naamàa man-the he circled fire he-was pulling meat 'the man circled the fire while he was dragging the meat' 'the man dragged the meat around the fire'

b. mahàdbii yaa hau tsaunìi yanàa jân muushèe hunter he climbed hill he-was pulling carion 'the hunter climbed the hill while he was dragging the carcass' 'the hunter dragged the carcass up the hill'

(19) a. *mùtumìn yaa jaa naamàa yanàa zaagàyà wutaa man-the he pulled meat he-was circling fire 'the man dragged the meat while he was circling the fire' 'the man dragged the meat around the fire'

b. *mahàdbii yaa jaa muushèe yanàa hawan tsaunìi hunter he pulled carion he-was climbing hill 'the hunter dragged the carcass up the hill' 'the hunter dragged the carcass while he was climbing the hill'

A far less frequent Hausa lexicalization pattern occurs in constructions where a noun form appears to convey Direction. In (20a) and (20b), a transitive and an intransitive manner verb appear with the spatial relation noun cikin 'inside' or 'belly'. This pattern, being confined to cikin, displays extremely limited distribution. It may be that constructions with cikin convey Direction only via implication, the non-directional relation between a moving entity and a locative reference point being re-interpreted by contextual implicature as directional. Nonetheless, Hausa's overall pattern for expressing manner of directional motion combines verb-framing of Motion+Direction with deranking of Manner under a condition of strict linear precedence.

(20) a. mùtumìn yaa tuurà amalanke cikin garkaa man.the he pushed wagon inside field 'the man pushed the wagon into the field'

b. yaaròo yaa ruugàa cikin daakìi boy he run inside room 'the boy ran into the room' 'the boy ran inside the house' 
3.2. Khoisan. Manner of motion events are linguistically structured in the Khoisan language !Xûu [Snyman 1970] by a strategy which retains verb framing. !Xûu links Motion+Direction to Manner by means of verb coordination or verb compounding. Verbs are not deranked one to another. Instead, the coordinator te 'and' is positioned between a Manner verb and a Motion+Direction verb. In (21), the intransitive verb !aa 'run', conveying Manner, stands coordinate with either of the Motion+Direction verbs $g$ !a?ama 'enter', //'hamm 'circle', g/ai 'exit', or $\neq$ xuru 'ascend.'

(21) a. !'hoama kaa !aa te g!a?ama tš'ul'ho boy the run and enter kraal 'the boy ran into the kraal'

b. da?ama kaa !aa te /l'hamm da?a child the run and circle fire 'the child ran and circled the fire' 'the child ran around the fire'

c. loe kaa !aa te g/ai tš' ul'ho horse the run and exit kraal 'the horse galloped and left the kraal' 'the horse galloped out of the kraal'

d. !'haa kaa !aa te $\neq$ xuru n! um antelope the run and ascend hill 'the antelope ran and ascended the hill' 'the antelope ran up the hill'

With transitive Manner verbs, !Xûu continues this strategy. Conjoined by te, transitive Manner verbs and their direct objects assume positions coordinate with Motion+Direction verbs. In (22), transitive /' hai 'drag', \|amm 'push', and !aa 'carry' are linked by te to the Motion+Direction verbs //'hamm 'circle', g!a?ama 'enter', g/ai 'exit', and $\neq$ xuru 'ascend.'

(22) a. !'hoa kaa /'hai !'ha te /l'hamm da?a man the drag meat and circle fire 'the man dragged the meat and circled the fire' 'the man dragged the meat around the fire'

b. !'hoa kaa \|amm kuni te g!a?ama tš' u|'ho man the push wagon andenter kraal 'the man pushed the wagon and entered the kraal' 'the man pushed the wagon into the kraal' 
c. dshau kaa !aa Pmsi te glai ťs' $i$ woman the carry food and exit bush 'the woman carried the food and left the bush' 'the woman carried the food out of the bush'

\section{d. !aakxaPao kaa /'hai !'haa te $\neq x u r u ~ n ! u m$} hunter the drag carcass and ascend hill 'the hunter dragged the carcass and ascended the hill' 'the hunter dragged the carcass up the hill'

Coordinate structures linking Manner and Motion+Direction verbs in !Xûu observe a relation of strict linear precedence. Manner must precede Motion+ Direction. The converse order, transitive or intransitive Manner verb following Motion+Direction verb, is not allowed. In (23a), g!a?ama 'enter' precedes !aa 'run' and, in (23b), // hama 'circle' precedes //'hai 'drag'. Since both are ungrammatical, !Xûu requires not only equivalent ranking of Manner and Motion+Direction verbs but also strict linear ordering between them.

(23) a. *!'hoama kaa g!a?ama tš'ul'ho te !aa boy the enter kraal and run 'the body entered the krall and ran' 'the boy ran into the kraal'

b. *!'hoa kaa /'hamm daPa te /'hai !'ha man the circle fire and drag meat 'the man circled the fire and dragged the meat' 'the man dragged the meat around the fire'

3.3. Nilo-Saharan. Manner of motion in Kanuri of the Nilo-Saharan phylum is expressed by verb coordination [Hutchison 1981, Cyffer 1994]. While retaining verb-framing of Motion+Direction, Kanuri conveys Manner through a second verb. Intransitive Manner verbs are linked to Motion+Direction verbs by the coordinating conjunction -ə 'and'. In (24), intransitive Manner səgas 'run' stands conjoined to either of the Motion+Direction verbs jawa 'ascend', kargawo 'enter', or culuwo 'exit, leave'.

(24) a. ngəri-do səgas-ə kawu-ro jəwa gazelle-the 3S.ran-and mountain-Go 3S.ascended 'the gazelle ran and ascended the mountain' 'the gazelle ran up the mountain' 
b. tada-də səgas-ə nyim-ro kargawo child-the 3S.ran-and room-Go 3S.entered

'the child ran and entered the room'

'the child ran into the room'

c. far-do səgas-ə suro fato-be-lan culuwo horse-the 3S.ran-and inside house-GEN-So 3S.left 'the horse ran and left the house' 'the horse ran out from inside the house'

Transitive verbs of Manner participate in a similar configuration. Coordination joins a transitive Manner verb and its accompanying direct object to a Motion+ Direction verb and its complement. In (25), -a conjoins, respectively, the Manner verbs $z u z$ 'push', goz 'take', and gərz 'drag' to Motion+Direction jowa 'ascend', kargawo 'enter', and doriz 'circle'.

(25) a. barama-ye tigə ngəri-be-do-ga zuz-ə hunter-NOM body gazelle-GEN-the-ACC 3S.pushed-and kawu-ro jowa mountain-Go 3S.ascended

'the hunter pushed the gazelle and ascended the mountain' 'the hunter pushed the gazelle up the mountain'

b. kam-do-ye babur-do-ga goz-ə suro person-the-NOM motorcycle-the-ACC 3S.took-and inside mowonti-be-ro kargawo school-GEN-Go 3S.entered

'the person brought the motorcycle and entered the school' 'the person brought the motorcycle into the school'

c. kam-do-ye da-də-ga gərz-ə kannu-do person-the-NOM meat-the-ACC 3S.dragged-and fire-the dəriz-ə kəlwono 3S.circled-and 3S.joined

'the person dragged the meat and circled the fire' 'the person dragged the meat around the fire'

Strict precedence constrains the ordering of Kanuri's Manner and Motion+ Direction verbs. Irrespective of their transitivity, Manner verbs do not follow 
Motion+Direction verbs. The coordinating conjunction $-\partial$, as demonstrated by the ungrammaticality in (26), never stands between Motion+Direction jaw 'climb, ascend' and Manner səgasa 'run', or between jəw and Manner zuz 'push'. Hence, expressing manner of motion in Kanuri also demands verbs of equivalent clausal rank in a strict linear order.

\section{(26) a. *ngəri-də kawu-ro jəw-ə səgasa gazelle-the mountain-Go 3S.climbed-and 3S.ran 'the gazelle climbed the mountain and ran' \\ 'the gazelle ran up the mountain'}

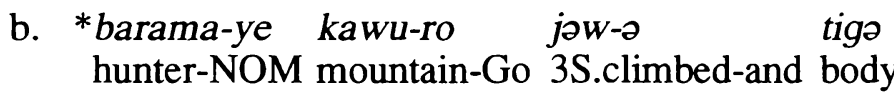

$$
\begin{array}{ll}
\text { ngəri-be-də-ga } & \text { zuz-ə } \\
\text { gazelle-GEN-the-ACC } & \text { 3S.pushed-and }
\end{array}
$$

'the hunter climbed the mountain and pushed the gazelle'

'the hunter pushed the gazelle up the mountain'

3.4. Niger-Kordofanian. Compared to other phyla in Africa, Niger-Kordofanian expresses manner of directional motion through a wider variety of syntactic strategies. It does so while retaining verb-framing for Direction. Analysis of languages such as Supyire, Emai, Tswana, and Shona reveals how Manner links to Motion+Direction through coordination, serialization, or clause level deranking.

The Gur language Supyire conveys manner of motion events via verb coordination. Manner and Motion+Direction verbs are ranked in a main clause as coordinate by a 'and'. The intransitive Manner verbs nya 'swim' and fe 'run' in (27) stand coordinate with the Motion+Direction verbs jyille 'cross', jye 'enter', or dugo 'ascend'.

(27) a. u a nya a ba-nyi jyiile

3S PRF swim and river-the cross

's/he swam and crossed the river'

's/he swam across the river'

b. $u$ a fe a jye ba-ge e

3S PRF run and enter house-the inside

's/he ran and entered the house' / 's/he ran into the house'

c. $u$ a fe a dugo nyang-ke na

3S PRF run and ascend hill-the LOC

's/he ran and ascended the hill'

's/he ran up the hill' 
Similarly, the transitive Manner verbs ngoonga 'push', filila 'drag', and dira 'pull' in (28) link via the coordinator a to the Motion+Direction verbs jyiile 'cross', dugo 'ascend', and fworo 'exit', respectively.

(28) a. u a ku ngoonga a ba-nyi jyiile

$3 \mathrm{~S}$ PRF it push and river-the cross

's/he pushed it and crossed the river'

's/he pushed it across the river'

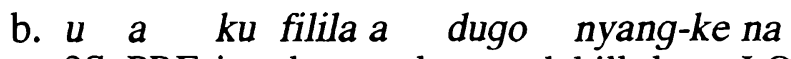

3S PRF it drag and ascend hill-the LOC

's/he dragged it and ascended the hill'

's/he dragged it up the hill'

c. $u$ a ku dira a fworo ba-ge e

3S PRF it pull and exit house-the inside

's/he pulled it and left the house'

's/he pulled it out of the house'

Verb coordination in Supyire appears to be controlled by strict linear precedence. It is ungrammatical, as shown in (29), for intransitive Manner nya 'swim' or transitive Manner ngoonga 'push' to follow Motion+Direction jyiile 'cross' and the coordinator a 'and'. Supyire's structuring of manner of motion therefore demands verbs of coordinate rank in strict linear order.

(29) a. ${ }^{*} u$ a ba-nyi jyiile a nya

3S PRF river-the cross and swim

's/he crossed the river and swam'

's/he swam across the river'

b. ${ }^{*} u$ a ba-nyi jyiile a ku ngoonga

3S PRF river-the cross and it push

's/he crossed the river and pushed it'

's/he pushed it across the river'

A syntactically distinct strategy for encoding manner of motion is employed by the Edoid language Emai [Schaefer 1987]. As with other Niger-Kordofanian languages, it retains verb-framing for lexicalizing Direction. To link Motion+ Direction and Manner verbs, Emai employs verb serialization which, unlike verb coordination, lacks overt morphological marking of rank. Verb serialization affects both transitive and intransitive manner verbs. Intransitive Manner la 'run' in (30) occurs in series with Motion+Direction $o$ 'enter', lagaa 'circle', or heen 'ascend'. 
(30) a. ólí ómohe lá ó vbi iwe the man run enter LOC house 'the man ran into the house'

b. ólí ómo $\underline{o} \quad \underline{o} \quad$ lá lágaa óli iwe the child SC CONT run circle the house 'the child is running around the house'

c. oóli ốmohe lá héén oóli oókoó the man run ascend the hill 'the man ran up the hill'

Similar structures are found with transitive Manner verbs. The verb sua 'push' and its direct object in (31) appear in series with Motion+Direction $o$ 'enter', lagaa 'circle' or heen 'ascend'.

(31) a. ốli ốmohe súá óli êkpete ó vbí ékóa the man push the stool enter LOC room 'the man pushed the stool into the room'

b. óli ógmohe $\underline{Q} \quad \underline{Q} \quad$ sua imátó lágaa óli iwe the man SC CONT push car circle the house 'the man is pushing the car around the house'

c. ólí oómohe súá oóli êkpete héén oólí oókoó the man push the stool ascend the hill 'the man pushed the stool up the hill'

Serialization, too, imposes a strict order condition on Emai verbs. When encoding a single motion event, it is never possible for either of the Manner verbs la 'run' or sua 'push' to follow the Motion+Direction verb $o$ 'enter' (32). Thus, Emai's serial verbs are characterized by equivalent rank in a coordinate structure and strict linear ordering.

(32) a. *ólí ómohe ó vbi iwe lá the man enter LOC house run 'the man ran into the house'

b. *oóli oómohe ó vbí ékóa súá óli e ekpete the man enter LOC room push the stool 'the man pushed the stool into the room' 
The Bantu language Tswana, in contrast, conveys manner of directional motion with clause level deranking. While holding to verb-framing for expressing Direction, Tswana relies almost exclusively on a multi-clause structure in which a deranked verb lexicalizes Manner and a main clause verb Motion+Direction. The intransitive Manner stem -tabog- 'run', for example, appears in a circumstantial or participial clause following either of the Motion+Direction stems - $t s w$ - 'exit' or -potolog- 'circle'. Deranking is signaled in part by a difference in subject concord prefixes, third person singular in circumstantial clauses being designated by a- and in main clauses by $o-$.
mò-símàné
ó-tsw-à
mó-tlù-ng
á-tábóg-à

1-boy he-exit-IMP inside-house-LOC he-run-IMP

'the boy is exiting the house while he is running'

'the boy is running out of the house'

b. mò-símàné ó-pótólòg-à pètsè á-tábóg-à

1-boy he-circle-IMP well he-run-IMP

'the boy is circling the well while he is running'

'the boy is running around the well'

In like manner, the transitive Manner stem -gog- 'pull' and its direct object occur in a circumstantial/participial clause following either of the Motion+ Direction stems -tsw- 'exit' or -potolog- 'circle.'

(34) a.

mò-símàné ó-tsw-à mó-lè-sàké-ng á-góg-á kòlói

1-boy he-exit-IMP in-5-kraal-LOC he-pull-IMP cart

'the boy is exiting the kraal while he is pulling a cart'

'the boy is pulling a cart out of the kraal'

b. mò-símàné ó-pótólòg-à pètsè á-góg-á kòlóí 1-boy he-circle-IMP well he-pull-IMP cart

'the boy is circling the well while he is pulling a cart' 'the boy is pulling a cart around the well'

Tswana manner of motion constructions impose strict ordering on their verbs. It is unacceptable, as indicated in (35), for the Manner stem -tabog- 'run' or -gog'pull' in a main clause to precede a Motion+Direction stem like -tsw- 'exit' in a circumstantial clause. Tswana thus deranks Manner verbs and strictly orders them after a Motion+Direction verb.

(35) a.

*mò-símàné ó-tábóg-à á-tsw-à mó-tlù-ng
1-boy he-run-IMP he-move out-IMP inside-house-LOC
'the boy is running out of the house'



b. *mò-símàné ó-góg-á kòlóí á-tsw-à mó-lè-sàké-ng 1-boy he-pull-IMP cart he-moveout-IMP in-5-kraal-LOC 'the boy is pulling a cart out of the kraal'

Also available in Tswana is an alternative lexicalization for one directional type [Cole 1955]. It pertains to the Direction 'into'. Verb stems like -tabog- 'run' and -gog- 'pull', but only when joined by the Direction conveying Applicative suffix $-\varepsilon l-$, conflate Manner+Motion (36). Since such constructions are limited to a single direction, Tswana's typical lexicalization pattern remains verb-framing with respect to Direction in the main clause and verb deranking of Manner in a subordinate clause.

(36) a. mò-símàné ó-tábóg-èl-à mó-tlù-ng
1-boy he-run-APP-IMP inside-house-LOC
'the boy is running into the house'

b. mò-símàné ó-góg-èl-á kòlói mó-kàgò-ng
1-boy he-pull-APP-IMP cart inside-building-LOC
'the boy is pulling a cart into the building'

A variation of the Tswana pattern for encoding manner of motion is evident in the Bantu language Shona [Fortune 1955]. It employs clause level deranking but fails to observe strict linear precedence. Despite this, it still holds to verb-framing for Direction. Shona allows a multi-clause structure in which a Manner verb occurs either deranked in a circumstantial/participial clause or ranked in a main clause. The intransitive Manner stem -mhany- 'run' reveals these distributional options in multi-clause structures with the Motion+Direction stems -pind- 'enter' and -poterer- 'circle'. Manner conveying -mhany- can be found in a participial clause marked by -chi- (PRT), which follows a main clause defined by -pind- (37a) or -poterer- (37c). And -mhany-can occur in a main clause preceding a -chi-marked participial clause containing -pind- (37b) or -poterer- (37d).

(37) a. mu-ana u-aka-pinda mumba a-chi-mhany-a

1-child 1-PST-enter room 1-PRT-run

'the child ran into the room'

'the child entered the room while he ran'

b. mu-ana u-aka-mhanya a-chi-pinda mumba

1-child 1-PST-run 1-PRT-enter room

'the child ran into the room'

'the child ran while he entered the room' 


\section{c. mu-ana u-aka-poterera tafura a-chi-mhanya 1-child 1-PST-circle table 1-PRT-run 'the child ran around the table' 'the child circled the table while he ran'}

\section{d. mu-ana u-aka-mhanya a-chi-poterera tafura 1-child 1-PST-run 1-PRT-circle table 'the child ran around the table' 'the child ran while he circled the table'}

Shona's transitive Manner stems, such as -kwev- 'drag', manifest comparable behavior. As verb of a -chi- marked participial clause, $-k w e v$ - follows a Motion+Direction main clause verb, -pind- 'enter', in (38a) and -tenderer- 'circle' in $(38 \mathrm{c})$. As a main clause verb, $-k w e v$ - precedes the participial clause Motiont Direction verbs -pind-in (38b) and -tenderer- in (38d).

(38) a. mu-rume u-aka-pinda mumba a-chi-kweva chitunha 1-man 1-PST-enter room 1-PRT-drag carcass 'the man dragged the carcass into the room' 'the man entered the room while he dragged the carcass'

b. mu-rume u-aka-kweva chitunha a-chi-pinda mumba 1-man 1-PST-drag carcass 1-PRT-enter room 'the man dragged the carcass into the room' 'the man dragged the carcass while he entered the room'

c. mu-rume u-aka-tenderera tsime a-chi-kweva chitunha 1-man 1-PST-circle well 1-PRT-drag carcass 'the man dragged the carcass around the well' 'the man circled the well while he dragged the carcass'

d. mu-rume u-aka-kweva chitunha a-chi-tenderera tsime 1-man 1-PST-drag carcass 1-PRT-circle well 'the man dragged the carcass around the well' 'the man dragged the carcass while he circled the well'

Shona presents the option of conflating Manner and Motion in the stems -mhany- 'run' and -kwev- 'drag', (39), but only so long as the Applicative suffix -er- is present to convey Direction. Since patterns of this type are limited to the Direction 'into', Shona's principal strategy for encoding manner of motion deranks either a Manner or Motion+Direction verb without strictly ordering them. 
(39) a. mu-ana u-aka-mhany-era mumba

1-child 1-PST-run-APP room

'the child ran into the room'

b. *mu-ana u-aka-mhanya mumba

1-child 1-PST-run room

c. mu-rume u-aka-kwev-era chitunha mumba

1-man 1-PST-drag-APP carcass room

'the man dragged the carcass into the room'

d. mu-rume u-aka-kwev-era mumba chitunha

1-man 1-PST-drag-APP room carcass

'the man dragged into the room the carcass'

e. *mu-rume u-aka-kweva chitunha mumba

1-man 1-PST-drag carcass room

Shona exhibits still another strategy for expressing Manner, Motion, and Direction, although not as elements of a single event. In construction with the consecutive morpheme -ka- (CONS), a Manner verb and a Motion+Direction verb appear in separate clauses referring to distinct events. The Manner stems -mhany'run' and $-k w e v-$ 'drag' stand in a consecutive relation to the Motion+Direction stem -pind- 'enter' in (40). Either verb type, as comparison of (40a) with (40b) and (40c) with (40d) attests, is found in a -ka- marked consecutive clause.

(40) a. chi-komana chi-aka-mhanya chi-ka-pinda mumba

7-boy 7-PST-run 7-CONS-enter room

'the boy ran and then he entered the room'

*'the boy ran into the house'

b. chi-komana chi-aka-pinda mumba chi-ka-mhanya

7-boy 7-PST-enter room 7-CONS-run

'the boy entered the room and then he ran'

* 'the boy ran and then he entered the room'

c. mu-rume u-aka-kweva chitunha a-ka-pinda mumba

1-man 1-PST-drag carcass 1-CONS-enter room

'the man dragged the carcass and then he entered the room'

*'the man dragged the carcass into the room' 


\section{d. mu-rume u-aka-pinda mumba a-ka-kweva chitunha 1-man 1-PST-enter room 1-CONS-drag carcass 'the man entered the room and then he dragged the carcass' *'the man dragged the carcass into the room'}

\section{Discussion}

In this paper we have reviewed the lexical and syntactic coding of directional motion events in each of the four language phyla of Africa. We uncovered a relatively consistent lexicalization of basic directional motion which is maintained under varying syntactic conditions to express manner of directional motion. Although the size of our database is limited, each phylum, Nilo-Saharan, AfroAsiatic, Khoisan, and Niger-Kordofanian, manifests the incorporation of Motion and Direction in a main clause verb. Each also assigns Manner, when present, to a distinct verb which is ranked as coordinate or is deranked via clause subordination or adposition phrasing. Except in the case of Shona, verb ranking and deranking occur under a condition of strict linear precedence.

With respect to basic directional motion, our primary conclusion is that African languages tend to be verb-framing rather than satellite-framing. In each phylum, conceptual material conveying motion and the direction of motion exhibit a strong propensity for merger in a single verb, i.e., Motion+Direction. Assuming the general validity of this conclusion leads to several questions for which answers are not yet available from very many individual African languages or their respective phyla. For instance, does the Motion+Direction merger hold for every directional type expressing transextensional motion? In the case of Tswana and Emai, transextensional direction types are characteristically verb framed [Schaefer 1985, 1986]. That is, they are colloquial, frequent, and pervasive in the grammatical system [Talmy 1985]. For other languages, it remains to be determined how extensively this merger holds. In this regard, Talmy [1983] postulates several directional configurations as possible universals that might fruitfully be investigated. A second question pertains to the relationship between transextensional and transpositional motion. Do the two rely on the same set of grammatical resources? Is direction conveyed by the same grammatical forms in both domains? If not, where do they differ? Beyond directional types, there is a need to assess the relation of Motion+Direction verbs to deixis. Particularly vexing in this regard is the possible combinatorial potential of Motion+Direction verbs and their deictic motion counterparts comparable to come and go.

Manner of directional motion expressed through transitive or intransitive verbs yielded several distinct strategies for linking Manner to Motion+Direction. Table I summarizes strategies found in each phylum. It reveals that syntactic arrangement of manner of directional motion across African languages does not tend toward a single pattern of articulation. Khoisan and Nilo-Saharan share a single strategy, verb coordination, which is also found in Niger-Kordofanian but not Afro-Asiatic. 
Table I. Distribution of lexicalization types and their linear order for manner of motion events in Khoisan (K), Nilo-Saharan (N-S), Afro-Asiatic (A-A) and NigerKordofanian (N-K).

\begin{tabular}{|c|c|c|c|}
\hline $\mathrm{K}$ & [MANNER] & cor & [MOTION+DIRECTION] \\
\hline $\mathrm{N}-\mathrm{S}$ & [MANNER] & cor & [MOTION+DIRECTION] \\
\hline \multirow[t]{2}{*}{ A-A } & [MOTION+DIRECTION] & & [ adp [MANNER] ] \\
\hline & [MOTION+DIRECTION] & & [ cir [MANNER] ] \\
\hline \multirow[t]{4}{*}{ N-K } & [MANNER] & cor & [MOTION+DIRECTION] \\
\hline & [MANNER] & ser & [MOTION+DIRECTION] \\
\hline & [MOTION+DIRECTION] & & [cir [MANNER] ] \\
\hline & [MANNER] & & [cir [MOTION+DIRECTI \\
\hline
\end{tabular}

Abbreviations designating verb rank: "cor"=coordinate conjunction, "adp"=adposition, "cir"= circumstantial clause, and "ser"=serialization.

Conversely, it is Niger-Kordofanian and Afro-Asiatic which share the circumstantial clause strategy, i.e., clause deranking, not found in Khoisan or NiloSaharan. The remaining two strategies, adposition marking, i.e., phrasal deranking of verb forms, and verb serialization, occur only within the phyla Afro-Asiatic and Niger-Kordofanian, respectively.

Additional investigation will be required to detail relations between these ranking and deranking strategies, especially as they occur within a single phylum. It would appear useful, for instance, to examine clause deranking in NigerKordofanian as it relates to serialization and coordination. Moreover, the propensity across phyla to constrain the linear ordering of Manner and Motion+ Direction verbs according to their ranked or unranked status requires attention. Languages like Shona which appear to disregard this constraint require more intensive analysis.

Future studies of individual languages will also need to determine whether conclusions arising from our initial analysis generalize to all transextensional manner of motion events. In other words, do individual Manner verbs combine with all basic Motion+Direction verbs to express transextensional motion? Do only some combine? If the latter, what grammatical resources are exploited to express directionality? A case in point is the alternative lexicalization for the direction 'into' discovered in Tswana, Shona, and Hausa. Extensive investigation of these 
and other questions might profit from our postulate that African languages will tend to fuse Motion and Direction in a verb while expressing Manner separately in a verb of the same or different rank.

As a final note, the results of this investigation bring to light several gaps in our understanding of the motion domain in individual African languages and their respective phyla. Information of the sort required for this study is not easily available in grammars or dictionaries. We hope, therefore, that the tentative, initial nature of this inquiry will spur sustained, intensive analysis of the motion domain in more African languages.

\section{REFERENCES}

Abraham, R.C. 1962. Dictionary of Modern Yoruba. London: Hodder Stoughton.

Carlson, Robert. 1994. A Grammar of Supyire. Berlin: Mouton de Gruyter.

Cole, Desmond T. 1955. Introduction to Tswana Grammar. London and Capetown: Longmans.

Creider, Chet (ed.). 1993. A Grammar of Kenya Luo (Dholuo) by A.N. Tucker. Köln: Rüdiger Köppe Verlag.

Creider, Chet and Jane Tapsubei Creider. 1993. A Grammar of Nandi. Hamburg: Buske.

Cyffer, Norbert. 1994. English-Kanuri Dictionary. Köln: Rüdiger Köppe Verlag.

De Wolf, Paul. 1995. English-Fula Dictionary. Berlin: Dietrich Reimer Verlag.

Dickens, Patrick. 1994. English-Ju'hoan: Ju'hoan-English_Dictionary. Köln: Rüdiger KöppeVerlag.

Dimmendaal, Gerrit. 1983. The Turkana Language. Dordrecht: Foris.

Dixon, R.M.W. 1982. Where Have All The Adjectives Gone? The Hague: Mouton.

Fortune, G. 1955. An Analytical Grammar of Shona. London and Capetown: Longmans. 
Frajzyngier, Zygmunt. 1987. "Encoding locative in Chadic." Journal of West African Languages XVII,1: 81-97.

Gruber, Jeffrey. 1976. Lexical Structures in Syntax and Semantics. Amsterdam: North Holland.

Hagman, Roy. S. 1977. Nama Hottentot Grammar. Bloomington: Indiana University.

Hutchison, John P. 1981. The Kanuri Language: A Reference Grammar. Madison: University of Wisconsin, African Studies Center.

Ikoro, Suanu. 1996. The Kana Language. Leiden: Research School CNNS.

Jackendoff, Ray. 1983. Semantics and Cognition. Cambridge, MA: MIT Press.

Jackendoff, Ray. 1990. Semantic Structures. Cambridge, MA: MIT Press.

Jakobi, Angelika. 1990. A Fur Grammar. Hamburg: Buske.

Kraft, G.H. and A.H.M. Kirk-Greene. 1973. Hausa. London: Hodder and Stoughton.

Leslau, Wolf. 1973. English-Amharic Context Dictionary. Wiesbaden: Harrassowitz.

Levin, Beth and Malka Rappaport-Hovav. 1995. Unaccusativity: At the SyntaxLexical Semantics Interface. Cambridge, MA: MT Press.

Newman, Paul and Roxana Ma Newman. 1977. Modern Hausa-English Dictionary. Zaria: Oxford University Press.

Schaefer, Ronald. 1985. "Motion in Tswana and its characteristic lexicalization." Studies in African Linguistics 16,1: 57-87.

Schaefer, Ronald. 1986. "Lexicalizing directional and nondirectional motion in Emai.” Studies in African Linguistics 17,2: 177-198.

Schaefer, Ronald. 1987. An Initial Lexicon and Orthography for Emai: An Edoid Language of Nigeria. Bloomington: Indiana University Linguistics Club. 
Shibatani, Masayoshi. 1976. "The grammar of causative constructions: A Conspectus." In M. Shibatani (ed.), The Grammar of Causative Constructions (Syntax and Semantics Volume 6). New York: Academic Press. Pp. 1-40.

Snyman, Jan. 1970. An Introduction to the !Xû Language. Pretoria: Balkema.

Talmy, Leonard. 1976. "Semantic causative types." In M. Shibatani (ed.),The Grammar of Causative Constructions (Syntax and Semantics Volume 6). New York: Academic Press. Pp. 43-116.

Talmy, Leonard. 1983. "How language structures space." Spatial Orientation: Theory, Research and Application, ed. by Herbert Pick, Jr. and Linda Acredolo. New York: Plenum Press. Pp. 225-282.

Talmy. Leonard. 1985. "Lexicalization patterns: Semantic structure in lexical forms." Language Typology and Syntactic Description: Grammatical Categories and the Lexicon, ed. by T. Shopen. New York: Cambridge University Press. Pp. 57-149.

Talmy, Leonard. 1991. "Path to realization: A typology of event integration." Proceedings of the Berkeley Linguistic Society 17: 480-519. Berkeley: University of California at Berkeley.

Traill, Anthony. 1994. A !Xóó Dictionary. Köln: Rüdiger Köppe Verlag.

Uwalaka, M.A.A.N. 1988. The Igbo Verb. Wien: Beiträge zur Afrikanistik.

Wehr, Hans. 1979. A Dictionary of Modern Written Arabic (4th ed.). Edited by J. Milton Cowan. Wiesbaden: Harrassowitz.

Welmers, Beatrice and William Welmers. 1968. Igbo: A Learner's Dictionary. Los Angeles: African Studies Center, University of California.

Department of English

Southern Illinois University

Edwardsville, IL 62026

Email: rschaef@siue.edu
[Received February, 1997; provisional acceptance June, 1997 final acceptance November, 1997] 